\title{
Isolation and structure elucidation of izuminosides A-C: a rare phenazine glycosides from Streptomyces sp. IFM 11260
}

\author{
Mohamed S Abdelfattah ${ }^{1,2}$, Kazufumi Toume $^{1}$ and Masami Ishibashi ${ }^{1}$ \\ Three new glycosylated phenazine derivatives, named izuminosides A-C (1-3) have been isolated from the ethyl acetate extract \\ of Streptomyces sp. IFM 11260. The structures of the new compounds were determined on the basis of their spectral data. \\ Compounds 1-3 were evaluated for their activity in overcoming tumor necrosis factor-related apoptosis-inducing ligand (TRAIL) \\ resistance in human gastric adenocarcinoma cells. Compounds $2(10 \mu \mathrm{M})$ and $3(60 \mu \mathrm{m})$ in combination with TRAIL showed \\ synergistic activity in sensitizing TRAIL-resistance AGS cells.
}

The Journal of Antibiotics (2011) 64, 271-275; doi:10.1038/ja.2010.172; published online 9 February 2011

Keywords: glycosides; phenazine; Streptomyces; TRAIL

\section{INTRODUCTION}

Phenazines comprise a large group of nitrogen-containing heterocyclic compounds that differ in their chemical and physical properties based on the type and position of functional groups present. Bacteria are the only known source of natural phenazines. The Gram-negative pathogen Pseudomonas was known as the first natural source that produces phenazine pigments. ${ }^{1}$ Other phenazine producers include Nocardia, Sorangium, Brevibacterium, Burkholderia, Erwinia, Pantoea agglomerans, Vibrio, Pelagiobacter ${ }^{2,3}$ and members of the actinomycetes, especially Streptomyces. ${ }^{4-6}$ More than 100 different phenazine structural derivatives have been identified in nature, and over 6000 compounds that contain phenazine as a central moiety have been synthesized. However, the carbohydrate-containing phenazine natural products are rare in nature. Only a few examples exist, all derived from 6-deoxy-L-glycopyranosides and exhibiting antibacterial activity. $^{7}$

In the course of our screening program for bioactive natural products from actinomycetes, ${ }^{8}$ we collected soils and seawaters from different areas of Japan. From a soil sample collected from Izumi forest at Chiba city (Japan), we isolated the Streptomyces sp. IFM 11260. Its crude extract showed on the TLC several relatively polar yellow bands, which seems dark under UV light $(254 \mathrm{~nm})$. These bands gave a dark red color with concentrated sulfuric acid and turned to reddish brown after spraying with the Dragendorff's reagent. In this paper, we report isolation, structure determination and biological activity of three new glycoconjugated phenazines designated as izuminosides A-C (1-3) from the culture extract of Streptomyces sp. IFM 11260 (Figure 1).

\section{RESULTS AND DISCUSSION}

\section{Structure elucidation}

The terrestrial Streptomyces sp. IFM 11260 was cultured in Waksman medium ${ }^{9}$ at $28^{\circ} \mathrm{C}$ for 5 days on a rotary shaker. After centrifugation, extraction and evaporation, working up of the crude extract resulted in the isolation of izuminosides A-C (1-3). Compound $\mathbf{1}$ was isolated as a yellow solid. The UV spectrum showed maxima at 365 and $259 \mathrm{~nm}$. The ESI-MS of 1 displayed in the positive ion mode a mass of $\mathrm{m} / \mathrm{z} 409.1[\mathrm{M}+\mathrm{Na}]^{+}$, suggesting a molecular weight of $386 \mathrm{Da}$. The molecular formula was determined as $\mathrm{C}_{19} \mathrm{H}_{18} \mathrm{~N}_{2} \mathrm{O}_{7}$ by HRESI-MS $\mathrm{m} / \mathrm{z}$ $409.1042[\mathrm{M}+\mathrm{Na}]^{+}($calcd $409.1012, \Delta+3.1 \mathrm{mmu})$. The ${ }^{1} \mathrm{H}$ NMR of 91 (Table 1) showed six aromatic protons in two 1,2,3-trisubstituted aromatic spin systems $\left(\mathrm{H}-2, \mathrm{H}-3\right.$ and $\mathrm{H}-4, \delta_{\mathrm{H}} 7.80(\mathrm{~d}, 8.0), 7.77$ $(\mathrm{t}, 8.0)$ and $8.13(\mathrm{~d}, 8.0) ; \mathrm{H}-7, \mathrm{H}-8$ and $\mathrm{H}-9, \delta_{\mathrm{H}} 7.46(\mathrm{~d}, 7.7), 7.69(\mathrm{t}, 7.7)$ and $7.88(\mathrm{~d}, 7.7))$. The aliphatic pattern revealed signals between $\delta_{\mathrm{H}}$ 5.70-3.45 and one methyl doublet typical for 6-deoxyhexapyranose at $\delta_{\mathrm{H}}$ 1.15. The ${ }^{13} \mathrm{C}$ NMR spectrum revealed 19 signals, which were assigned to one carbonyl $\left(\delta_{\mathrm{C}} 176.1\right)$, one oxygenated $s p^{2}$ carbon $\left(\delta_{\mathrm{C}} 152.8\right)$, six $s p^{2}$ aromatic methine carbons $\left(\delta_{\mathrm{C}} 131.6,131.5,129.7\right.$, $128.3,124.6$ and 114.2$)$ and five $s p^{2}$ quaternary carbons $\left(\delta_{\mathrm{C}} 145.4\right.$, $143.2,142.0,137.8$ and 131.0). In the sugar region, one-anomeric carbon signal $\left(\delta_{\mathrm{C}} 101.3\right)$, four oxygenated methine carbons $\left(\delta_{\mathrm{C}} 73.9\right.$, $72.3,71.9$ and 71.2$)$ and one methyl group $\left(\delta_{\mathrm{C}} 18.0\right)$ were observed. The structure of 1 was clarified by analyses of the 2D NMR spectra $\left({ }^{1} \mathrm{H}^{-1} \mathrm{H}\right.$ COSY, HMQC and HMBC). From the ${ }^{1} \mathrm{H}^{-1} \mathrm{H}$ COSY, two spin aromatic systems were established (Figure 2). The HMBC spectrum of 1 also suggested that izuminoside A (1) had 6-hydroxy-phenazine-1carboxylic acid aglycone (H-2/C-11, C-10a, C-4; H-3/C-1; H-4/C-4a,

${ }^{1}$ Graduate School of Pharmaceutical Sciences, Chiba University, Chiba, Japan and ${ }^{2}$ Chemistry Department, Faculty of Science, Helwan University, Cairo, Egypt Correspondence: Professor M Ishibashi, Graduate School of Pharmaceutical Sciences, Chiba University, 1-33 Yayoi-cho, Inage-ku, Chiba 263-8522, Japan, E-mail: mish@faculty.chiba-u.jp

Received 13 October 2010; revised 11 December 2010; accepted 14 December 2010; published online 9 February 2011 


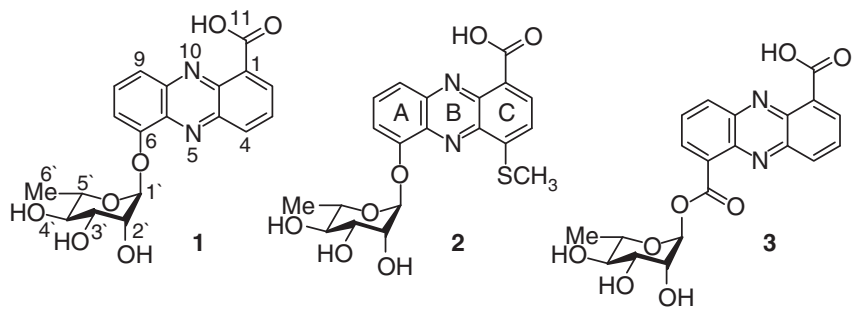

Figure 1 Structures of izuminosides A-C (1-3).
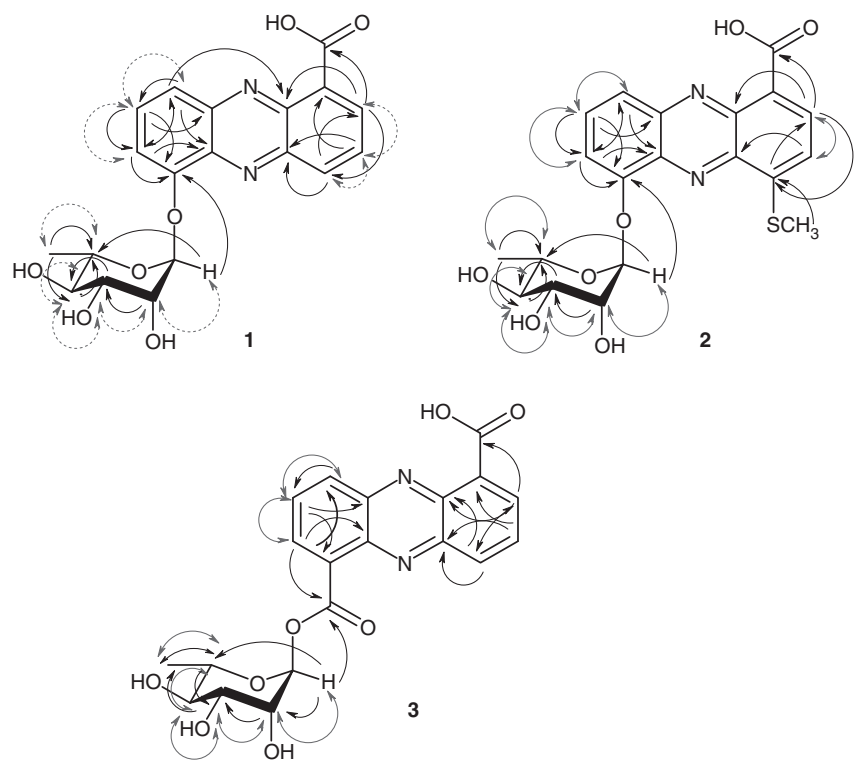

Figure $2 \mathrm{HMBC}(\curvearrowright)$ and ${ }^{1} \mathrm{H}-{ }^{1} \mathrm{H}-\mathrm{COSY}(\curvearrowleft)$ NMR correlations of compounds 1-3.

C-2; H-7/C-9, C-6, C-5a; H-8/C-9a, C-6 and H-9/C-10a, C-7, C-5a). The aglycone was also confirmed by comparison of the spectral data with the literature values. ${ }^{10}$ From the analysis of ${ }^{1} \mathrm{H}-{ }^{1} \mathrm{H}$ COSY spectra and the coupling pattern of each $\mathrm{H}$-signal, the $\mathrm{O}$-glycosidic moiety in compound 1 could be deduced as 6-deoxyhexapyranose. The connectivity of the 6-deoxysugar to the aglycone was confirmed from the HMBC long-range coupling of $\mathrm{H}-8\left(\delta_{\mathrm{H}} 7.69\right)$ and $\mathrm{H}-1^{\prime}\left(\delta_{\mathrm{H}} 5.70\right)$ to the C-6 $\left(\delta_{\mathrm{C}} 152.8\right)$ of the phenazine nucleus.

Compound 2 was obtained as an orange solid. It gave a yellow fluorescent spot under UV light at $366 \mathrm{~nm}$. The molecular weight of 2 was determined as $432 \mathrm{Da}$ based on the $(+)$-ESI-MS. The molecular formula was estimated as $\mathrm{C}_{20} \mathrm{H}_{20} \mathrm{~N}_{2} \mathrm{O}_{7} \mathrm{~S}$ by HRESI-MS $m / z 455.0890$ $[\mathrm{M}+\mathrm{Na}]^{+}($calcd $455.0889, \Delta+0.1 \mathrm{mmu})$. The ion peak fragment at $m / z 309.03264[\mathrm{M}+\mathrm{Na}]^{+}$(calcd for $\mathrm{C}_{14} \mathrm{H}_{10} \mathrm{~N}_{2} \mathrm{O}_{3} \mathrm{~S}, \Delta+1.7 \mathrm{mmu}$ ) was assigned to the aglycone of 2 . The UV spectrum recorded in $\mathrm{MeOH}$ (maxima at 271, 366 and $454 \mathrm{~nm}$ ) suggested a phenazine nucleus. The ${ }^{1} \mathrm{H}$ NMR data of 2 (Table 1 ) recorded in DMSO- $d_{6}$ indicated one $\mathrm{D}_{2} \mathrm{O}$ exchangeable proton (11-OH, $\delta \mathrm{H} 14.70$ (brs)), two ortho-coupled aromatic signals $\left(\mathrm{H}-2\right.$ and $\mathrm{H}-3, \delta_{\mathrm{H}} 8.52(\mathrm{~d}, 8.1)$ and $7.74(\mathrm{~d}, 8.1)$ ), three aromatic protons in $\mathrm{ABC}$ system $\left(\mathrm{H}-7, \mathrm{H}-8\right.$ and $\mathrm{H}-9, \delta_{\mathrm{H}} 7.62$ $(\mathrm{d}, 8.6), 8.00(\mathrm{t}, 8.6)$ and $8.03(\mathrm{~d}, 8.6))$, many aliphatic signals typical for 6-deoxysugar residue $\left(\delta_{\mathrm{H}} 5.81-1.09\right)$ and one singlet attributable to $-\mathrm{SCH}_{3}$ group $\left(\delta_{\mathrm{H}} 2.66(\mathrm{~s})\right)$. The ${ }^{13} \mathrm{C}$ NMR spectrum of 2 showed only one carbonyl $\left(\delta_{\mathrm{C}} 166.1\right)$, one $s p^{2}$ carbon connected to sulfur atom $\left(\delta_{\mathrm{C}} 148.7\right)$, five $s p^{2}$ methine carbons $\left(\delta_{\mathrm{C}} 134.6,132.8,122.2,121.3\right.$ and
$114.9)$ and also four quaternary $s p^{2}$ carbons $\left(\delta_{\mathrm{C}} 141.5,141.3,139.7\right.$ and 135.4). The spectrum also revealed the six carbons for the 6-deoxysugar and one methyl group $\left(\delta_{\mathrm{C}} 13.9\right)$. Several of the relevant carbon chemical shifts were, however, obtained only by interpretation of HMBC and HMQC NMR data. Interpretation of the HMBC spectrum of 2 confirmed the structure of ring A (1,2,3-trisubstituted benzene ring) as in 1 . The ortho-positioned aromatic protons $\mathrm{H}-2$ $\left(\delta_{\mathrm{H}} 8.52\right)$ and $\mathrm{H}-3\left(\delta_{\mathrm{H}} 7.74\right)$ showed a long-range HMBC correlations to the C-11 $\left(\delta_{\mathrm{C}} 166.1\right), \mathrm{C}-10 \mathrm{a}\left(\delta_{\mathrm{C}} 139.7\right), \mathrm{C}-3\left(\delta_{\mathrm{C}} 122.2\right)$; and C-4a $\left(\delta_{\mathrm{C}} 138.5\right)$, respectively. As the aromatic proton $\mathrm{H}-2\left(\delta_{\mathrm{H}} 8.52\right)$ and the $-\mathrm{SCH}_{3}$ group $\left(\delta_{\mathrm{H}} 2.66\right)$ coupled to $\mathrm{C}-4\left(\delta_{\mathrm{C}} 148.7\right)$, the methylsulfanyl group must be located at $\mathrm{C}-4$ in a para-position to the carboxylic acid group in ring $\mathrm{C}$. These couplings construct the aglycone of compound 2 as shown in Figure 2. The position of the 6-deoxysugar was determined from the interpretation of the HMBC spectrum, which exhibited correlation from the anomeric proton $\mathrm{H}^{-1} 1^{\prime}\left(\delta_{\mathrm{H}} 5.81\right)$ to the C-6 $\left(\delta_{\mathrm{C}} 151.2\right)$ of the phenazine moiety.

Compound 3 was isolated as yellow solid. It was revealed to have the molecular formula of $\mathrm{C}_{20} \mathrm{H}_{18} \mathrm{~N}_{2} \mathrm{O}_{8}$ on the basis of HRESI-MS, at $m / z 437.0975\left([\mathrm{M}+\mathrm{Na}]^{+}, \Delta+1.4 \mathrm{mmu}\right)$. The ${ }^{1} \mathrm{H}$ NMR and ${ }^{13} \mathrm{C}$ NMR spectra of 3 (Table 1) were similar to those of 1 except in the presence of an extra carbonyl $\left(\delta_{\mathrm{C}} 164.8\right)$ for 3 in place of oxygenated $s p^{2}$ carbon at $\mathrm{C}-6$ for $\mathbf{1}$. The HMBC correlations of 3 allowed the construction of phenazine-1,6-dicarboxylic acid (H-2/C-11, C-10a, C-4; H-3/C-4a, C-1; H-4/C-10a, C-4a, C-2; H-7/C-12, C-9, C-5a; H-8/ C-9a, C-6 and $\mathrm{H}-9 / \mathrm{C}-7)$. The long-range $\mathrm{HMBC}$ couplings of the aromatic signal $\mathrm{H}-7\left(\delta_{\mathrm{H}} 8.42\right)$ and the anomeric proton $\left(\delta_{\mathrm{H}} 6.18\right)$ with the ester carbonyl carbon $\left(\delta_{\mathrm{C}} 164.8\right)$ indicated that the sugar unit linked to the phenazine nucleus through an ester linkage.

The relative stereochemistry for the 6-deoxyhexopyanose in compounds 1-3 was determined by the nuclear overhauser effect (NOE) and coupling constants. The NOE observed between $3^{\prime}-\mathrm{H}$ and $5^{\prime}-\mathrm{H}$ as well as the coupling constant between $4^{\prime}-\mathrm{H}$ and $5^{\prime}-\mathrm{H}\left(J_{4}^{\prime}, 5^{\prime} 9.4-9.7 \mathrm{~Hz}\right)$ indicated that they were axially oriented. The configuration of the anomeric proton of compounds $\mathbf{1}-\mathbf{3}$ was assigned to be $\alpha$ based on the

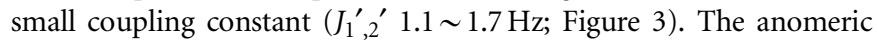
configuration for the 6-deoxysugar was also deduced as $\alpha$ from the one-bond coupling constant between $\mathrm{C}-\mathrm{1}^{\prime}$ and $\mathrm{H}-\mathrm{I}^{\prime}$ (Rha, $J_{\mathrm{Cl}}{ }^{\prime}{ }_{\mathrm{H} 1}{ }^{\prime}$ values: 171.8-175.2 Hz observed for $1-3$; literature values ${ }^{11} \alpha$-anomer, $172.3 \mathrm{~Hz}$; $\beta$-anomer, $160 \mathrm{~Hz}$ ). On the basis of these results, the sugar moiety in compounds 1-3 was identified as rhamnose. It was confirmed by the HPLC analysis (SHISEIDO CO., LTD, Tokyo, Japan, $85 \% \mathrm{CH}_{3} \mathrm{CN}$ ) of the crude sugar obtained by acidic hydrolysis of izuminosides $\mathrm{A}-\mathrm{C}$ (1-3). The absolute configuration of the sugar residue was determined to be L-rhamnose by comparison with the authentic samples using a combination of the refractive index and optical rotation detectors. From all of these results, the structure of izuminosides A-C (1-3) was determined to be 6-(1'-O- $\alpha$-L-rhamanopyranosyl)-phenazine-1-carboxylic acid, 4-methylsulfanyl-6-(1'-O- $\alpha$-L-rhamanopyranosyl)-phenazine-1carboxylic acid and 6-(1'-O- $\alpha$-L-rhamano-pyranosyloxycarbonyl)phenazine-1-dicarboxylic acid ester, respectively. From the literature, phenazoviridine was the first glycoconjugated phenazine obtained from actinomycetes. ${ }^{12}$ Other examples of carbohydrate containing phenazines are aestivopheonins $\mathrm{A}-\mathrm{C},{ }^{13} 2-\mathrm{O}$ and 3-O-L-quinovosyl esters of saphenic acid. ${ }^{14}$

\section{Biological activity}

We evaluate the bioactivity of izuminosides A-C (1-3) for their activity in overcoming tumor necrosis factor-related apoptosisinducing ligand (TRAIL) resistance in AGS cells. Recently, this cell line has been widely used as a model system for evaluating 
Table $1{ }^{1} \mathrm{H}$ and ${ }^{13} \mathrm{C}$ NMR data for compounds $1-3$

\begin{tabular}{|c|c|c|c|c|c|c|}
\hline \multirow[b]{2}{*}{ Position } & \multicolumn{2}{|c|}{$1^{\mathrm{a}}$} & \multicolumn{2}{|c|}{$2^{\mathrm{b}}$} & \multicolumn{2}{|c|}{$3^{\mathrm{b}}$} \\
\hline & $\delta_{H}($ p.p.m.) & $\delta_{C}(p . p . m)$. & $\delta_{H}($ p.p.m.) & $\delta_{C}($ p.p.m.) & $\delta_{H}($ p.p.m.) & $\delta_{C}$ (p.p.m.) \\
\hline 2 & 7. $80 \mathrm{~d}(8.0)$ & 128.3 & $8.52 \mathrm{~d}(8.1)$ & 134.6 & $8.50 \mathrm{~d}(7.0)$ & 134.1 \\
\hline 3 & $7.77 \mathrm{t}(8.0)$ & 131.5 & $7.74 \mathrm{~d}(8.1)$ & 122.2 & $8.12 \mathrm{t}(7.0)$ & 133.2 \\
\hline 4 & $8.13 \mathrm{~d}(8.0)$ & 129.7 & - & 148.7 & $8.55 \mathrm{~d}(7.0)$ & 129.5 \\
\hline 6 & - & 152.8 & - & $151.2^{\mathrm{c}}$ & - & 130.9 \\
\hline 7 & $7.46 \mathrm{~d}(7.7)$ & 114.2 & $7.62 \mathrm{~d}(8.6)$ & 114.9 & $8.42 \mathrm{~d}(6.9)$ & 133.3 \\
\hline 8 & $7.69 \mathrm{t}(7.7)$ & 131.6 & $8.00 \mathrm{t}(8.6)$ & 132.8 & $8.12 \mathrm{t}(6.9)$ & 131.3 \\
\hline 9 & $7.88 \mathrm{~d}(7.7)$ & 124.6 & $8.03 \mathrm{~d}(8.6)$ & 121.3 & $8.56 \mathrm{~d}(6.9)$ & 132.9 \\
\hline $9 a$ & - & 145.4 & - & 141.3 & - & 140.5 \\
\hline $10 a$ & - & 143.2 & - & 139.7 & - & 142.6 \\
\hline $3^{\prime}$ & $4.15 \mathrm{dd}(9.7,3.8)$ & 72.3 & $3.94 \mathrm{dd}(9.4,3.8)$ & 69.4 & 3.76 dd $(9.4,3.8)$ & 70.2 \\
\hline $4^{\prime}$ & $3.45 \mathrm{t}(9.7)$ & 73.9 & $3.39 \mathrm{t}(9.4)$ & 71.8 & $3.42 \mathrm{t}(9.4)$ & 71.5 \\
\hline $5^{\prime}$ & $3.73 \mathrm{dq}(9.7,6.3)$ & 71.2 & $3.69 \mathrm{dq}(9.4,6.6)$ & 69.9 & $4.04 \mathrm{dq}(9.4,5.9)$ & 71.6 \\
\hline $6^{\prime}$ & $1.15 \mathrm{~d}(6.3)$ & 18.0 & $1.09 \mathrm{~d}(6.6)$ & 17.9 & $1.24 \mathrm{~d}(5.9)$ & 18.0 \\
\hline $4-\mathrm{SCH}_{3}$ & - & - & $2.66 \mathrm{~s}$ & 13.9 & - & - \\
\hline $11-\mathrm{OH}$ & - & - & $14.70 \mathrm{brs}$ & - & $14.31 \mathrm{brs}$ & - \\
\hline $2^{\prime}-\mathrm{OH}$ & - & - & $5.15 \mathrm{brs}$ & - & $5.28 \mathrm{brs}$ & - \\
\hline $3^{\prime}-\mathrm{OH}$ & - & - & 4.83 brs & - & 4.78 brs & - \\
\hline $4^{\prime}-\mathrm{OH}$ & - & - & $4.94 \mathrm{brs}$ & - & 5.05 brs & - \\
\hline
\end{tabular}

aData was measured in $\mathrm{CD}_{3} \mathrm{OD}$.

bata measured in DMSO- $d_{6}$.

'Values observed from HMBC.

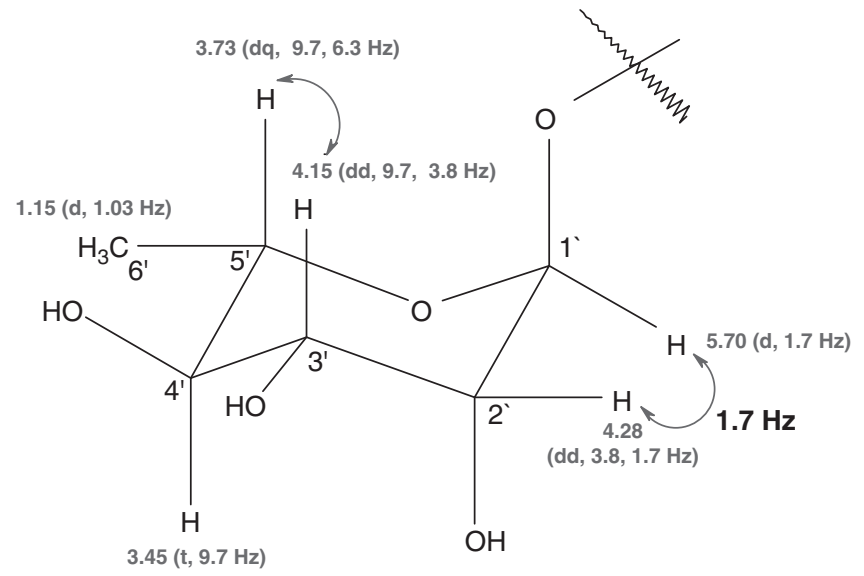

Figure 3 Selected NOE correlations $(\curvearrowleft)$ and coupling constant in the sugar moiety of $\mathbf{1}$.

cancer cell apoptosis and is reported to be refractory to apoptosis induction by TRAIL. ${ }^{15}$ To assess the effects of compounds 1-3 on cell viability, in the presence and absence of TRAIL, AGS cells were treated with the indicated agents and subjected to fluorometric microculture cytotoxicity assay method. ${ }^{16}$ Luteolin was used as a positive control at $18.0 \mu \mathrm{M} .{ }^{17}$ The assay results (Figure 4) showed that compounds $2(10 \mu \mathrm{M})$ and $3(60 \mu \mathrm{M})$ exhibited 22 and $19 \%$ decreases, respectively, in cell viability in the presence

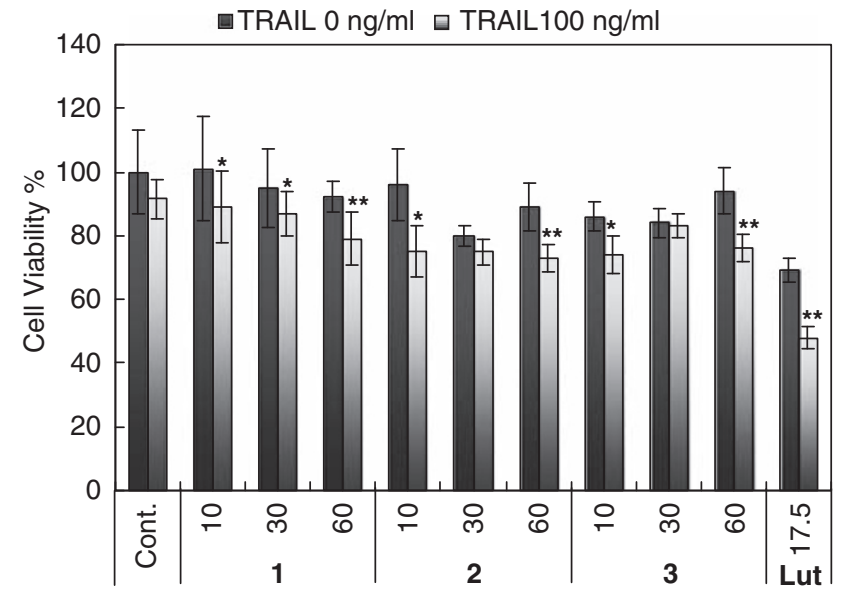

Figure 4 Effect of the isolated compounds $1-3$ on the cell viability of AGS cells in the presence and absence of TRAIL. The standard error bar represents the means $(n=3 \pm$ s.d. $)$. The significance difference was determined by Student's $t$-test ( ${ }^{* *} P<0.01 ;{ }^{*} P<0.05$ versus control).

of TRAIL $\left(100 \mathrm{ng} \mathrm{ml}^{-1}\right)$ compared with in the absence of TRAIL. Compound 1, however, did not show TRAIL-resistance overcoming activity. These results suggest that izuminosides B (2) and C (3) had a synergistic effect in combination with TRAIL against AGS cells. 
The resistance of cancer cells toward TRAIL may occur at different points in the TRAIL-induced apoptotic pathways. Understanding the mechanisms of such resistance and developing strategies to overcome it are important for the successful use of TRAIL in cancer therapy. Combined treatment with TRAIL and chemotherapeutic agents, including natural products can overcome such resistance and sensitize TRAIL-resistant cells to enhance the therapeutic potential of TRAIL against cancer cells. Therefore, a natural product producing synergistic activity with TRAIL would be a new tool for investigating cancer cells. ${ }^{18}$ In this study, we report for the first time the synergistic activity (albeit small) of glycosylated phenazine in sensitizing TRAIL-resistant AGS cells, thereby suggesting their possible use in combination with TRAIL against human gastric adenocarcinoma. The antimicrobial activity of izuminosides A-C (1-3) was also examined against Bacillus subtilis, but they were inactive at $50 \mu \mathrm{g}$ per disk.

Overall, our search for new bioactive natural products from actinomycetes yielded the terrestrial Streptomyces sp. IFM 11260, which produced three new phenazine derivatives with 6-deoxysugar moity for further exploration. The strain may become a valuable resource for generating novel phenazines- $\mathrm{O}$-glycosides through combinatorial biosynthesis. ${ }^{19}$

\section{METHODS}

\section{General experimental procedures}

Optical rotations were measured with a JASCO P-1020 polarimeter (JASCO, Tokyo, Japan). IR spectra were measured on attenuated total reflection on a JASCO FT-IR 230 spectrophotometer (JASCO). UV spectra were measured on a Shimadzu UV mini-1240 spectrometer (Shimadzu, Kyoto, Japan). The NMR spectra were recorded on JEOL JNM-ecp600 spectrometers (JEOL, Tokyo, Japan) with a deuterated solvent, the chemical shift of which was used as an internal standard (see Supplementary Information). Mass spectra were recorded on AccuTOF-T100LP (JOEL) mass spectrometer.

\section{Identification of the producing strain}

The strain IFM 11260 was isolated on humic acid-vitamin agar, ${ }^{20}$ a medium for the selective isolation of actinomycetes, from a soil sample collected from the Izumi forest, Chiba city, Japan in 2007. It was identified as Streptomyces sp. and deposited at the Medical Mycology Research Center, Chiba University, Japan with the code number IFM 11260. Identification of the strain was carried out by sequence analysis of $16 \mathrm{~S}$ ribosomal RNA gene using the DDBJ (DNA data bank of Japan)-BLAST (basic local alignment search tool) search. The strain was found to have $100 \%$ identity with the 16 S ribosomal RNA of Streptomyces spororaveus LMG 20313.

\section{Fermentation and isolation}

Spores of the Streptomyces sp. IFM 11260 growing on solid Waksman medium were inoculated into $4 \times 500 \mathrm{~cm}^{3}$ round-bottom flask each containing $100 \mathrm{ml}$ of liquid medium and then incubated at $28^{\circ} \mathrm{C}$ for 5 days with reciprocal shaking at 200 r.p.m. to produce seed culture. The seed culture $(10 \mathrm{ml})$ was then inoculated into each of 20 of 31 flasks each containing $700 \mathrm{ml}$ of liquid Waksman medium, and incubated at $28^{\circ} \mathrm{C}$ for 5 days with reciprocal shaking at 200 r.p.m. to get 141 of fermentation broths. The culture broth was centrifuged at 3500 r.p.m. for $20 \mathrm{~min}$ then extracted three times with ethyl acetate. The solvent was concentrated in vacuo to yield $2.67 \mathrm{~g}$ extract. The mycelial cake was extracted three times with acetone. After removal of acetone, the aqueous solution was extracted three times with EtOAc to give $0.57 \mathrm{~g}$ residue. The extracts from water phase and mycelial cake were combined after controlling by TLC. The crude extract $(3.24 \mathrm{~g})$ was fractionated using silica gel flash column chromatography through a stepwise gradient solvent system of increasing polarity starting from $100 \% \mathrm{CHCl}_{3}$ to $80 \% \mathrm{MeOH}$ to yield four fractions. Fraction II $(540 \mathrm{mg}$ ) was applied to Sephadex LH-20 (GE Healthcare BioScience, Uppsala, Sweden) $(\varphi 15 \times 600 \mathrm{~mm}, \mathrm{MeOH})$ to give three subfractions named IIa $(129.8 \mathrm{mg})$, IIb $(80.6 \mathrm{mg})$ and IIc $(260.9 \mathrm{mg})$. Sub-fraction IIb was purified by preparative TLC ( 6 plates, $20 \times 20 \mathrm{~cm}, \mathrm{CHCl}_{3} / 16 \% \mathrm{MeOH}$ ) to yield compounds 1 ( $8.0 \mathrm{mg})$ and $\mathbf{2}(1.6 \mathrm{mg})$. Purification of fraction III $(330.2 \mathrm{mg})$ using Sephadex LH-20 $(\varphi 15 \times 600 \mathrm{~mm}, \mathrm{MeOH})$ followed by preparative HPLC (Develosil ODS HG-5, Nomura Chemical Co., Ltd, Seto, Japan, $10 \times 250 \mathrm{~mm})$ afforded compound $3\left(5.4 \mathrm{mg}, R_{\mathrm{t}}=21.3 \mathrm{~min}\right)$. The mobile phase was gradients of $\mathrm{CH}_{3} \mathrm{CN} / \mathrm{H}_{2} \mathrm{O}$ at flow rate of $1.0 \mathrm{ml} \mathrm{min}^{-1}$.

\section{Acid hydrolysis of compounds 1-3 and determination of the} absolute configuration of the sugar

Compound 1 ( $4.2 \mathrm{mg})$ in 1,4-dioxane $(5.0 \mathrm{ml})$ and $5 \%$ aqueous $\mathrm{H}_{2} \mathrm{SO}_{4}(3 \mathrm{ml})$ was heated at $100^{\circ} \mathrm{C}$ under reflux for $3 \mathrm{~h}$. After cooling to room temperature, water was added to the reaction mixture, and the mixture was partitioned with EtOAc. The aqueous layer containing the sugar was neutralized by passage through an Amberlite IRA-96SB column, and then analyzed by HPLC (Capcell Pak $\mathrm{NH}_{2}$ UG80, $4.6 \times 250 \mathrm{~mm}$; eluent, $85 \% \mathrm{MeCN}$; flow rate, $0.7 \mathrm{ml} \mathrm{min}^{-1}$; column temperature, $40{ }^{\circ} \mathrm{C}$; detection, refractive index; and optical rotation, JASCO OR-2090). The sugar was identified as L-rhamnose by comparing its retention time and the optical rotation detector with both of authentic sample and the literature value ${ }^{21}\left(t_{\mathrm{R}} 7.29 \mathrm{~min}\right.$, negative peak in optical rotation detector). Compounds $\mathbf{2}$ and $\mathbf{3}$ were hydrolyzed and analyzed by the same procedures as above to give also the same sugar residue (L-rhamnose).

\section{Fluorometric microculture cytotoxicity assay}

AGS cells were seeded in a 96-well culture plate $(6 \times 103$ cells per well) in $200 \mu \mathrm{l}$ of RPMI medium containing $10 \%$ fetal bovine serum. ${ }^{16}$ Cells were incubated at $37^{\circ} \mathrm{C}$ in a $5 \% \mathrm{CO}_{2}$ incubator for $24 \mathrm{~h}$. Then the test samples with or without TRAIL (Wako, Osaka, Japan, $100 \mathrm{ng} \mathrm{ml}^{-1}$ ) at different doses were added to each well. After $24 \mathrm{~h}$ incubation, the cells were washed with phosphate-buffered saline, and $200 \mu \mathrm{l}$ of phosphate-buffered saline containing fluorescein diacetate $\left(10 \mu \mathrm{g} \mathrm{ml}^{-1}\right)$ was added to each well. The plates were then incubated at $37^{\circ} \mathrm{C}$ for $1 \mathrm{~h}$, and fluorescence was measured in a 96-well scanning spectrofluorometer at $538 \mathrm{~nm}$, following excitation at $485 \mathrm{~nm}$.

Izuminoside A (1) . Yellow solid, $[\alpha]_{\mathrm{D}}^{20}+22.3($ c $0.42, \mathrm{MeOH}) ; \mathrm{UV}(\mathrm{MeOH})$ $\lambda_{\max }(\log \varepsilon) 365(4.2)$ and $259(5.1) \mathrm{nm}$; IR $v_{\max }$ (attenuated total reflection) $\sim 3360,2917,1561,1407$ and $737 \mathrm{~cm}^{-1}$; ${ }^{1} \mathrm{H}$ and ${ }^{13} \mathrm{C}$ NMR data in Table 1; (+)-HRESI-MS $m / z 409.1042[\mathrm{M}+\mathrm{Na}]^{+}$(calcd for $\mathrm{C}_{19} \mathrm{H}_{18} \mathrm{~N}_{2} \mathrm{O}_{7} \mathrm{Na}, 409.1012$ ).

Izuminoside B (2). Yellow solid, $[\alpha]_{\mathrm{D}}^{20}+23.2($ c $0.12, \mathrm{MeOH})$; $\mathrm{UV}(\mathrm{MeOH})$ $\lambda_{\max }(\log \varepsilon) 454(4.3), 366(4.5)$ and $271(5.3) \mathrm{nm}$; IR $v_{\max }$ (attenuated total reflection) $\sim 3369,2919,2851,1731,1588,1092$ and $754 \mathrm{~cm}^{-1}$; ${ }^{1} \mathrm{H}$ and ${ }^{13} \mathrm{C}$ NMR data in Table 1; (+)-HRESI-MS $m / z 455.0890[\mathrm{M}+\mathrm{Na}]^{+}$(calcd for $\mathrm{C}_{20} \mathrm{H}_{20} \mathrm{~N}_{2} \mathrm{O}_{7} \mathrm{SNa}, 455.0889$ )

Izuminoside $C$ (3). Yellow solid, $[\alpha]^{20}{ }_{\mathrm{D}}+14.3(c$ 0.14, $\mathrm{MeOH}) ; \mathrm{UV}(\mathrm{MeOH})$ $\lambda_{\max }(\log \varepsilon) 206$ (3.9), 250 (4.3) and 367 (4.9) nm; IR $v_{\max }$ (attenuated total reflection) $\sim 3369(\mathrm{br}), 2917,2677,1706,1530,1263$ and $752 \mathrm{~cm}^{-1} ;{ }^{1} \mathrm{H}$ and ${ }^{13} \mathrm{C}$ NMR data in Table 1; (+)-HRESI-MS $\mathrm{m} / z$ $437.09751[\mathrm{M}+\mathrm{Na}]^{+}$(calcd for $\mathrm{C}_{20} \mathrm{H}_{18} \mathrm{~N}_{2} \mathrm{O}_{8} \mathrm{Na}$, 437.0962).

\section{CONFLICT OF INTEREST}

The authors declare no conflict of interest.

\section{ACKNOWLEDGEMENTS}

We are thankful to Professor Tohru Gonoi (Medical Mycology Research Center, Chiba University) for the identification of Streptomyces sp. IFM 11260. The research was supported by Grant in-Aid for Scientific Reserch from the Japan Society for the Promotion of Science, and MS Abdelfattah thanks JSPS for a postdoctoral fellowship (ID No. P09042).

1 Budzikiewicz, H. Secondary metabolites from fluorescent pseudomonads. FEMS Microbiol. Rev. 104, 209-228 (1993).

2 Mentel, M. et al. Of two make one: the biosynthesis of phenazines. Chem. Bio. Chem. 10, 2295-2304 (2009).

3 Mavrodi, D. V. et al. Diversity and evolution of the phenazine biosynthesis pathway. Appl. Environ. Microbiol. 76, 866-879 (2010). 
4 Turner, J. M. \& Messenger, A. J. Occurrence, biochemistry and physiology of phenazine pigment production. Adv Microb Physiol 27, 211-275 (1986).

5 Fotso, S. et al. Modified phenazines from an Indonesian Streptomyces sp. J. Nat. Prod. 73, 472-475 (2010).

6 Krastel, P., Zeeck, A., Gebhardt, K., Fiedler, H.- P. \& Rheinheimer, J. Endophenazines A-D, new phenazine antibiotics from the athropod associated endosymbiont Streptomyces anulatus. J. Antibiot. 55, 801-806 (2002).

7 Laursen, J. B. \& Nielsen, J. Phenazine natural products: biosynthesis, synthetic analogues, and biological activity. Chem. Rev. 104, 1663-1686 (2004).

8 Ahmed, F., Ohtsuki, T., Aida, W. \& Ishibashi, M. Tyrosine derivatives isolated from Streptomyces sp. IFM 10937 in a screening program for TRAIL-resistance overcoming activity. J. Nat. Prod. 71, 1963-1966 (2008).

9 Waksman, S. A. The Actinomycetes: Classification, Identification and Descriptions of Genera and Species vol. 2Williams \& Wilkins Co., Baltimore, 61-292 (1961).

10 Axel, R. ${ }^{1}$ H NMR spectra of substituted phenazines. Org. Magn. Reson. 19, 66-68 (1982).

11 Bock, K., Lundt, I. \& Pedersen, C. Assignment of anomer structure to carbohydrates through geminal ${ }^{13} \mathrm{C}-\mathrm{H}$ coupling constants. Tetrahedron Lett. 13, 1037-1040 (1973).

12 Kato, S. et al. Phenazoviridin, a novel free radical scavenger from Streptomyces sp. J. Antibiot. 46, 1485-1493 (1993).
13 Shin-Ya, K. et al. Novel neuronal cell protecting substances, aestivophoenins A and B, produced by Streptomyces purpeofuscus. J. Antibiot. 48, 1378-1381 (1995).

14 Pathirana, C., Jensen, P. R., Dwight, R. \& Fenical, W. Rare phenazine L-quinovose esters from a marine actinomycete. J. Org. Chem. 57, 740-742 (1992).

15 Srivastava, R. K. TRAIL/Apo-2L: mechanisms and clinical applications in cancer. Neoplasia 3, 535-546 (2001).

16 Larsson, R., Kristensen, J., Sandberg, C. \& Nygren, P. Laboratory determination of chemotherapeutic drug resistance in tumor cells from patients with leukemia, using a fluorometric microculture cytotoxicity assay (FMCA). Int. J. Cancer 50, 177-185 (1992).

17 Horinaka, M. et al. Luteolin induces apoptosis via death receptor 5 upregulation in human malignant tumor cells. Oncogene 24, 7180-7189 (2005).

18 Shankar, S. \& Srivastava, R. K. Enhancement of therapeutic potential of TRAIL by cancer chemotherapy and irradiation: mechanisms and clinical implications. Drug Resist. Updat. 7, 139-156 (2004).

19 Olano, C. et al. Glycosylated derivatives of steffimycin: insights into the role of the sugar moieties for the biological activity. Chembiochem. 9, 624-633 (2008).

20 Hayakawa, M. \& Nonomura, H. Humic acid-vitamin agar, a new medium for the selective isolationof soilactinomycetes. J. Ferment. Technol. 65, 501-509 (1987).

21 Kuroda, M. et al. Steroidal glycosides from the bulbs of Camassia leichtlinii and their cytotoxic activities. Chem. Pharm. Bull. 49, 726-731 (2001).

Supplementary Information accompanies the paper on The Journal of Antibiotics website (http://www.nature.com/ja) 